\title{
p107 in the public eye: an Rb understudy and more
}

\author{
Stacey E Wirt1,2 and Julien Sage $e^{* 1,2}$
}

\begin{abstract}
p107 and its related family members $\mathrm{Rb}$ and $\mathrm{p} 130$ are critical regulators of cellular proliferation and tumorigenesis. Due to the extent of functional overlap within the Rb family, it has been difficult to assess which functions are exclusive to individual members and which are shared. Like its family members, p107 can bind a variety of cellular proteins to affect the expression of many target genes during cell cycle progression. Unlike Rb and p130, p107 is most highly expressed during the $\mathrm{G} 1$ to $S$ phase transition of the cell cycle in actively dividing cells and accumulating evidence suggests a role for p107 during DNA replication. The specific roles for p107 during differentiation and development are less clear, although emerging studies suggest that it can cooperate with other Rb family members to control differentiation in multiple cell lineages. As a tumor suppressor, p107 is not as potent as Rb, yet studies in knockout mice have revealed some tumor suppressor functions in mice, depending on the context. In this review, we identify the unique and overlapping functions of p107 during the cell cycle, differentiation, and tumorigenesis.
\end{abstract}

\section{Review} Introduction

The $R b$ tumor suppressor was first identified as the gene whose loss causes hereditary retinoblastoma in children [1-4]. Further studies identified a variety of cancers with mutations in the $R b$ gene or deregulation of the $\mathrm{Rb}$ pathway, leading to the hypothesis that $\mathrm{Rb}$ is a major tumor suppressor whose loss of function is a common factor in most human tumors [5]. Independent studies with viral oncogenes such as SV40 Large $\mathrm{T}$ antigen, adenovirus E1A, and human papilloma virus E7 showed that Rb could be bound and inactivated by these oncoproteins, leading to the transformation of various cell types [6-11]. These discoveries have paved the way for over 20 years of studies on the mechanisms of cell cycle control and tumor suppression. But $\mathrm{Rb}$ was not the only protein that could bind to these viral oncoproteins, and the exact regions necessary for binding to $\mathrm{Rb}$ could also bind two other cellular proteins, eventually identified as p107 and p130 [11-13]. Together, the $R b$ gene family makes up a critical component of the cell cycle machinery and is conserved across many species [Reviewed in [14]]. However, we still do not have the answers to many essential questions about how these genes function and in what cellular context they are required for cell cycle control and tumor

\footnotetext{
* Correspondence: julsage@stanford.edu

1 Departments of Pediatrics and Genetics, Stanford Medical School, Stanford, CA 94305, USA

Full list of author information is available at the end of the article
}

suppression. Additionally, the overlapping functions of each of the three genes further complicates our understanding of how they control critical cellular functions such as exit from and entry into the cell cycle, differentiation, and cell death. We will focus this review on our understanding of p107 and what is known about its functions in the cell cycle, cellular differentiation, and tumor suppression.

\section{Evolution of the $\mathrm{Rb}$ gene family}

$R b$-related genes can be found across multiple species, including humans, mice, chickens, reptiles, flies, and even some plants. Most unicellular and lower organisms have only one $R b$-related gene, while higher organisms tend to have two or three family members, perhaps reflecting an increasing complexity of cell cycle control in these species. For example, the unicellular alga Chlamydomonas reinhardtii only contains one $R b$-like gene (mat3), whose loss leads to a deregulation of proliferation and a reduced cell size [15]. In yeast, the gene Whi5 appears to play a functionally similar role to $\mathrm{Rb}$, despite a lack of sequence homology [16-18]. Most plant species seem to contain only one $R b$-related gene, although recently a second $R b$ related gene was identified in maize and rice $[19,20]$. Caenorhabditis elegans also contains one $R b$-like gene, lin-35, which in sequence homology is more similar to $p 107$ than to $R b$ [21]. Further up the evolutionary scale, an independent gene duplication is thought to have created two $R b$-related genes in Drosophila, RBF1 and RBF2 
[22-24]. Like lin35 in C. elegans, these two genes are more similar to mammalian $p 107$ and $p 130$ than they are to $R b$ itself. Interestingly, the gene duplication events in plants and flies are only two examples of many duplication events within the $R b$-family over the course of evolution as additional duplication events have occurred in Gallus gallus (chicken), Danio rerio (zebrafish), and Anolis carolinensis (lizard) (Figure 1).

Based on the sequence similarities, many of the $R b$ related genes in non-mammals resemble $p 107$ or $p 130$ more so than $R b$, suggesting that $R b$ is likely to be the more recent addition to the family. In other words, $p 107$ and $p 130$ may be closer in sequence to the ancestral $R b$ gene than $R b$ itself. Regardless, it is striking that an ancestral $R b$-like gene existed and has evolved across numerous species, often independently undergoing duplication multiple times throughout evolution. Furthermore, once duplicated, these $R b$-related genes independently evolved complex regulatory systems in which one $R b$-related gene can be transcriptionally regulated by the other, as was observed in flies, plants, and mammals [25-27]. This repeated and independent evolution of the gene family and its associated regulatory networks emphasize the critical role the $R b$-related genes share in controlling the cell cycle across many different species. But why is there such a strong selection for multiple $R b$ genes across so many species? If two or more genes performed identical functions, then there would be no selection to keep all of them throughout evolution. One explanation for the selection to keep multiple $\mathrm{Rb}$ family members is that they have evolved unique functions in addition to their over-

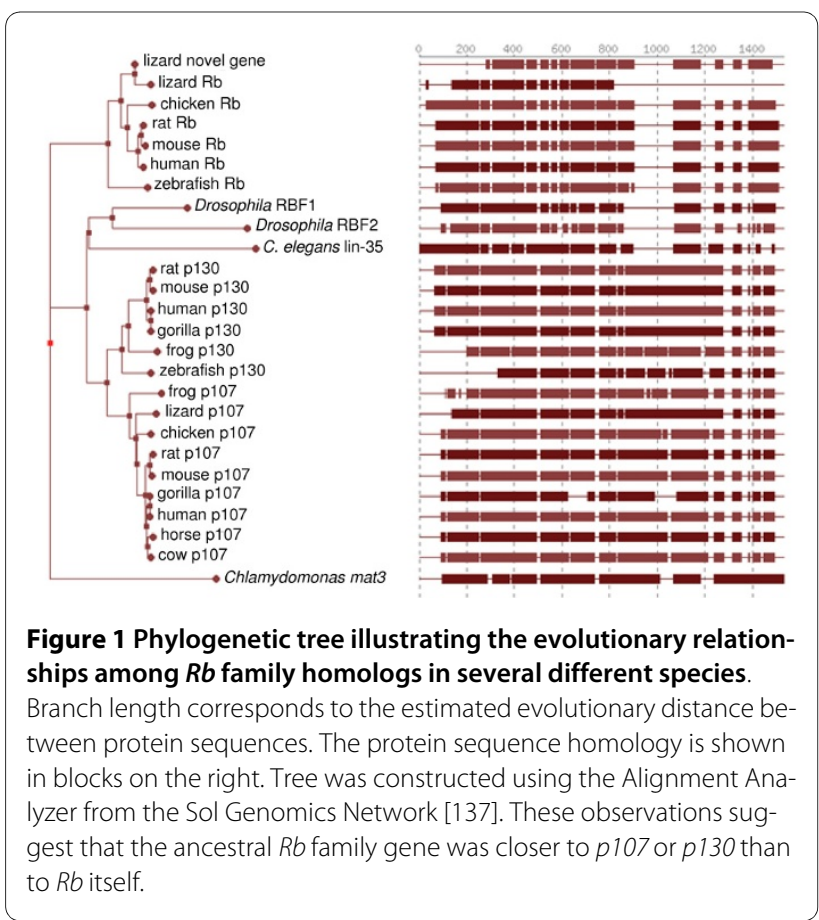

lapping functions, which would allow for individual members to be essential in different cellular processes or cell types [28,29]. Another explanation is that they may individually become more specialized after duplication, with one gene losing some functions in favor of others $[28,30]$. Finally, it is also possible that the regulatory regions surrounding the $\mathrm{Rb}$ family genes become mutated instead of the coding sequence itself [30]. This type of mutation would allow the proteins to retain redundant functions, but be regulated in different ways or expressed in different patterns throughout the organism. Given the wide variety of ways in which the individual $\mathrm{Rb}$ family members are expressed and their unique and overlapping cellular functions in different organisms, it is likely that the $\mathrm{Rb}$ gene family underwent multiple rounds of subfunctionalization and neofunctionalization over time. These observations raise the question of why p107 was retained throughout the evolution of higher organisms, and what specific functions it performs in mammalian cells.

\section{Characterization and expression}

p107, or Rb-like 1 (Rbl1) as it was originally named, was identified through its interaction with SV40 Large T antigen and adenovirus E1A [31]. Structurally, p107 contains a bipartite pocket structure similar to $\mathrm{Rb}$, but it shares more sequence homology with p130. Both p107 and p130 contain the $\mathrm{A}$ and $\mathrm{B}$ regions of the pocket domain separated by a spacer region. Both p107 and p130 also contain insertions in the $\mathrm{C}$-terminal $\mathrm{B}$ pocket that are absent from $\mathrm{Rb}$, as well as a distinct Cyclin-binding domain in the spacer region between the $\mathrm{A}$ and $\mathrm{B}$ pocket domains. Additionally, p107 and p130 also contain a Cdk inhibitor domain in the N-terminus that is not present in $\mathrm{Rb}$ (Figure 2).

Unlike Rb and p130, p107 levels are generally, but not always, low in quiescent and differentiated cells and higher when cells proliferate [32-37]. p107 molecules can be detected in both the cytoplasm and the nucleus in various cell types. It is thought that p107 binds to repressor E2F family members such E2F4 in the cytoplasm to bring these repressors to their target genes in the nucleus $[38,39]$. During G1 and in early S phase of the cell cycle, high-resolution deconvolution microscopy has revealed that p107 and its family members can be found in perinuclear foci, where they co-localize with E2Fs and HDAC proteins $[40,41]$. These complexes are largely found in interchromatin regions, where active transcription is thought to occur. Whereas p130/E2F4 complexes are mainly found in G0 and G1 phase, p107/E2F4 complexes increase after G1 and are largely found in S phase [41]. These data suggest that p107 can recruit transcription factors from the cytoplasm and the nucleus to regulate 


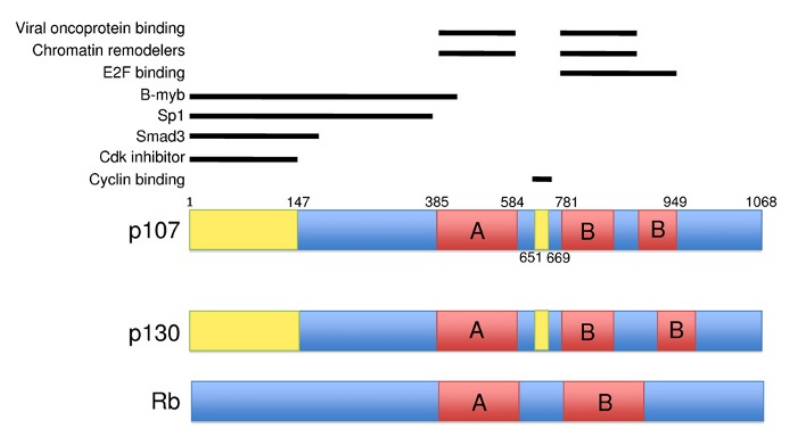

Figure 2 Schematic diagram of the shared domains for $\mathrm{p} 107$, p130, and Rb. p107 and p130 are more similar to each other than to $\mathrm{Rb}$ due to more extensive sequence homology and the shared Cyclin binding and Cdk inhibitory domains. Regions of p107 known to be important for specific protein interactions are shown above in blocked lines. The minimal sequences required for binding Sp1 and B-myb have not yet been identified, however the region $\mathrm{N}$-terminal from the pocket domains has been shown to be critical for binding to both proteins.

transcription at the promoters of actively transcribed genes.

Of the three $\mathrm{Rb}$ family members, $\mathrm{p} 107$ is thought to be the most heavily regulated at the transcriptional level [26,36]. p107 itself is a known E2F target gene, containing two E2F consensus sites in its promoter [27]. Upon Rb ablation, increased E2F activity is thought to cause an increase in p107 expression, which may be able to compensate for the loss of $\mathrm{Rb}$ in certain contexts [42-44]. Indeed, many cell types express increased levels of p107 in the absence of $\mathrm{Rb}$ [45-49]. One hypothesis is that $\mathrm{Rb}$ directly controls p107 expression through direct binding to E2Fs at the p107 promoter. Interestingly, in the absence of p107, no significant increase is seen in Rb or p130 [50], suggesting that one of the main functions of p107 may be to serve as a backup for loss of Rb.

\section{Cell cycle functions}

p107, like p130 and Rb, is a substrate for Cyclin/Cdk kinase activity during cell cycle progression, which is thought to cause p107 to release E2F transcription factors and relieve repression of target gene promoters [51-54]. In quiescent cells, p107 is usually expressed at low levels and is generally hypophosphorylated similarly to $\mathrm{Rb}$; p107 becomes phosphorylated as cells progress towards $S$ phase, with the first phosphorylation events occurring roughly when Cyclin D/Cdk4 is activated [33,55]. Thus, the highest expression levels of p107 in S phase correlate to a time when the protein is functionally deactivated by phosphorylation. After S phase, p107 remains phosphorylated throughout the rest of the cell cycle until the next G1 phase, when it is rapidly dephosphorylated, presumably by phosphatase $2 \mathrm{~A}$, and can bind E2F target genes in late $\mathrm{G} 1$ and $\mathrm{S}$ phase before it is hyperphosphorylated again [56-59].

Once bound to E2Fs, Rb family members repress transcription through a variety of methods. The $\mathrm{Rb}$ family can directly recruit chromatin modifying enzymes such as histone deacetylase HDAC1 (Figure 2), which alters chromatin structure around the E2F site to repress transcription at E2F target genes [60-68]; alternatively, Rb family members may interfere with pre-initiation complex assembly at the promoters of E2F target genes [69]. While $\mathrm{Rb}$ mainly associates with E2F1, E2F2, E2F3, and E2F4 in vivo, p107 preferentially binds to E2F4 and E2F5 at the promoters of E2F target genes in cycling cells [7077]. In quiescent cells, p107 levels are generally low, and not detected at target gene promoters [56]. In the absence of $\mathrm{Rb}$, however, p107 may play a compensatory role and can be found in complex with E2F1-3 [70], and transcription of E2F targets can be regulated normally, at least in certain contexts [45]. Interestingly, in the combined absence of p107 and p130, some E2F target genes are deregulated such as those coding for E2F1, Cyclin A2, Bmyb, DHFR, and Cdc2, and these targets are different than the ones deregulated in the absence of $\mathrm{Rb}$ [45]. This evidence suggests that $\mathrm{Rb}$ cannot compensate for the loss of p107 and p130 at certain promoters, and that certain E2F target genes rely on either $\mathrm{Rb}$ or $\mathrm{p} 107 / \mathrm{p} 130$ for normal expression and regulation. While the basis for this specificity is unknown, it points to some unique functions of p107 and p130 that are distinct from Rb. A remaining question is whether $\mathrm{p} 107$ and p130 themselves share the same targets, or whether they each bind to a distinct set of E2F target genes in vivo. Future experiments should aim to identify more extensive sets of target genes bound by individual $\mathrm{Rb}$ family members in various cellular contexts. Experiments such as genome-wide chromatin immunoprecipitation followed by sequencing (ChIP-Seq) with antibodies specific to p107, p130, and Rb in different cell types or at different phases of the cell cycle may help to shed light on this question.

In addition to its role as a transcriptional repressor of E2F activity, p107 may also control entry into $\mathrm{S}$ phase by regulating the levels of the F-box protein Skp2 within a cycling cell. p107 can down-regulate Skp2 levels, causing the stabilization of the cell cycle inhibitor p27 [78]. Stabilized p27 can then bind and inhibit Cyclin E/Cdk2 complexes, which are essential for the progression into $\mathrm{S}$ phase $[78,79]$.

Recent evidence further points to a unique role for p107 during S phase, in addition to its function in late G1. While SAOS-2 cells transiently transfected with physiologic levels of Rb arrest in G1, the same cells transfected with physiologic levels of p107 arrest in both G1 and S phase [80]. A small pool of under-phosphorylated p107 
persists throughout S-phase, and this pool may interact with other cell cycle regulators such as Smad3 to repress transcription of cell cycle genes like $c-M y c$ [77]. In response to DNA damaging agents such as UV irradiation or addition of cisplatin, p107 can be rapidly dephosphorylated in cells progressing though $\mathrm{S}$ phase $[81,82]$, and the phosphatase responsible for the de-phosphorylation of p107 may be protein phosphatase 2A [59,82]. This increase in hypophosphorylated p107 in response to DNA damage is independent of p53 or p21 activity, as cells with a null mutation in either inhibitor can still dephosphorylate p107 after DNA damage [82]. This evidence suggests a model in which massive dephosphorylation of p107 in response to genotoxic stress can contribute to the DNA damage response by invoking cell cycle arrest, although the exact mechanisms for how p107 induces an S-phase arrest are still unknown.

p107 and p130 bind to and inhibit Cyclin E/Cdk2 and Cyclin $\mathrm{A} / \mathrm{Cdk} 2$ kinases through a unique spacer region in between the $\mathrm{A}$ and $\mathrm{B}$ pockets that is not present in $\mathrm{Rb}$ (Figure 2) [52,74,83-89]. This region is phosphorylated when bound by Cyclin/Cdk complexes [88]. In addition to the spacer region, there is a domain in the amino-terminus of both pl07 and p130 that can inhibit Cyclin/Cdk kinase activity similarly to the Cyclin-dependant kinase inhibitors p21 and p27 [83,88,89]. p107/Cyclin/Cdk complexes can be found in two distinct populations within a cell: those that contain E2F4/DP complexes and those that do not [89]. Recent evidence suggests that Cyclin D1 itself can bind to the promoters of many genes [90], and it would be interesting to determine whether Cyclin D binding had any correlation to known p107 or E2F target genes.

Through its N-terminus region, p107 binds the transcription factor $\mathrm{Sp} 1$ and represses $\mathrm{Sp} 1$ transcriptional activation, and this interaction may be unique to p107 among $\mathrm{Rb}$ family members [91,92]. In transient transfection assays [91], p107 can repress Sp1 transcription activation, and endogenous Sp1/p107/E2F4 complexes have been identified at the promoter of the Fgfrl gene in chick myoblasts [92]. Additionally, the $\mathrm{N}$-terminal domain of p107 can bind to the transcription factor B-myb, which competes with binding of Cyclin/Cdk complexes and prevents their sequestration by $\mathrm{p} 107$ [93]. The $\mathrm{N}$-terminus of p107 can also bind to Smad3 in response to TGF $\beta$ signaling, and in this context p107 serves as an adaptor that is required to bring both E2F4-5/DP complexes and Smad3 to the nucleus. Once in the nucleus, p107/E2F4-5/Smad3 complexes bind to the promoter of $c-M y c$ and repress its transcription. This interaction can explain how TGF $\beta$ signaling is able to selectively repress $c-M y c$ transcription upstream of Cyclin/Cdk inactivation, and it is a unique function of p107, as Rb and p130 are unable to bind to Smad3 [77]. Interestingly, p107 can also directly bind c-
Myc through the pocket domain and prevent its transactivation in transient transfection assays $[94,95]$. These experiments provide additional evidence for the many ways in which p107 is able to inhibit cell cycle progression through multiple interactions with various transcription factors and other proteins in addition to E2F (Summarized in Table 1).

\section{In vivo phenotypes for loss of $\mathrm{p} 107$ function in mice}

Proper development requires the tight integration of cell cycle control, differentiation signals, migration, and cell death. Interestingly, numerous studies have demonstrated that $\mathrm{Rb}$ can not only affect cell cycle arrest in multiple cell lineages, but it can also interact with tissuespecific differentiation factors to promote the transcription of differentiation genes [Reviewed in [96-98]]. Like $\mathrm{Rb}, \mathrm{p} 107$ has also been implicated in the regulation of numerous cell types during development, however its specific functions in different cell types are much less well defined. Does p107 affect differentiation largely though its influence on cell cycle control? Or can it, like Rb, integrate control of classical cell cycle genes and tissue-specific differentiation genes?

p107-deficient mice in a mixed 129/Sv:C57/BL6 background are viable and fertile, and mouse embryonic fibroblasts (MEFs) derived from these animals display no significant cell cycle defects [50]. Interestingly, $p 107$-deficient mice in a Balb/c background show a severe postnatal growth deficiency, as well as myeloid hyperplasia in the spleen and liver. MEFs and myoblasts derived from these animals exhibit increased proliferation that was associated with constitutive expression of Cyclin E [99]. These mice have a significant decrease in white adipose tissue differentiation, although this decrease in differentiation was shown to be due to the fact that $p 107^{-/}$pre-adipocytes could not upregulate $\mathrm{Rb}$, which is required to initiate differentiation in vivo through interaction with $\operatorname{Pgc1\alpha }$ [100].

p107 and p130 seem to play overlapping roles during embryonic development in the mouse, and one reason for the lack of severe phenotypes in the $p 107 \%$ mouse may be due to compensation from $\mathrm{p} 130$ or Rb. $p 107^{-/} ; p 130^{-/}$ embryos die at birth with multiple defects in tissue development. Interfollicular keratinocytes from $p 107^{-/} ; p 130^{--}$ newborns show impaired terminal differentiation in the epidermis, decreased numbers of hair follicles, and a developmental delay in hair, whisker, and tooth formation [101]. These defects may be due to a general decrease in the amount of critical signaling molecules such as BMP and p63 in the double knockout epidermis, and implies that p107 can contribute to epithelial development along with p130.

p107 has also been implicated in the control of bone and cartilage development. Double knockout p107/ 
Table 1: Summary of functional differences between p107, Rb, and p130.

\begin{tabular}{|c|c|c|c|c|}
\hline Function & p107 & p130 & $\mathbf{R b}$ & References \\
\hline Binds to Smad3 & yes & no & no & [77] \\
\hline Binds to Sp1 & yes & no & no & [91] \\
\hline Binds to c-Myc & yes & unknown & no & {$[94,95]$} \\
\hline Binds to Cyclins & yes & yes & no & {$[51,83-86,89,140]$} \\
\hline $\begin{array}{c}\text { Regulates } \\
\text { chrondrocyte } \\
\text { development in vivo }\end{array}$ & yes & yes & no & {$[58,102-104,139]$} \\
\hline $\begin{array}{l}\text { Regulates neural } \\
\text { precursor populations } \\
\text { through FGF and Hes } 1 \\
\text { in vivo }\end{array}$ & yes & no & no & {$[105,108,112]$} \\
\hline $\begin{array}{l}\text { Regulates cerebellar } \\
\text { granule cell survival }\end{array}$ & yes & no & yes & [113] \\
\hline Tumor suppressor & weak & weak & yes & $\begin{array}{c}{[44,49,122,123,129,131} \\
-133,141]\end{array}$ \\
\hline
\end{tabular}

;p 130/- embryos as well as $p 107^{-/} ; p 27^{-/}$embryos display defects in ossification of the long bones and chondrocyte proliferation [102,103]. During chondrogenesis, FGF signaling induces a potent cell cycle arrest, and dephosphorylation of p107 is one of the earliest distinguishing events during this process, occurring 10-11 hours sooner than dephosphorylation of Rb and p130 [104]. Overexpression of Cyclin/Cdk complexes in developing chondrocytes prevented the dephosphorylation of p107 and completely abolished the growth suppression affects mediated by FGF signaling [58]. Biochemical studies in these cells have identified an interaction between the protein phosphatase PP2A and p107, suggesting a model in which FGF signaling stimulates PP2A to rapidly dephosphorylate p107, which results in a robust cell cycle arrest (Figure 3). Interestingly, FGF signaling in most other cells types has the opposite affect on cell growth; FGF signaling in these tissues triggers rapid phosphorylation of $\mathrm{Rb}$ family members and cell proliferation.

In the adult mouse brain, p107 expression is unique from the other $\mathrm{Rb}$ family members in that it is restricted to cycling progenitor cells in the ventricular zone, and its expression decreases as these cells begin to differentiate into cortical neurons [46,105]. Rb itself remains fairly consistently expressed throughout the transition from progenitor to neuron, and p130 expression increases with neuronal differentiation $[106,107]$. In the developing cortex of the mammalian brain, p107 may regulate the decision for a progenitor cell to exit the cell cycle and commit to a neuronal fate (Figure 3). p107 has been shown to negatively regulate neural precursor cell self-renewal both in vitro and in vivo [105]. Newly committed neurons that lack p107 die in the ventricular zone (VZ) before they can begin migrating out of the VZ or express markers associated with neuronal differentiation [108]. This apoptosis in the ventricular zone causes mice without p107 to have decreased numbers of neurons in the developing frontal cortex.

The mechanisms for how p107 can control cell cycle exit and fate decisions in neural progenitors are still relatively unknown. One potential explanation is that p107 acts through the repression of Hes1, a key downstream target of the Notch signaling pathway, since p107-deficient animals display increased Hes1 signaling (Figure 3). Several E2F binding sites have been located in the Hes1 promoter, and loss of one allele of Hes1 is enough to partially restore the numbers of neural progenitors to wild type levels in $p 107^{-/}$brains [108]. This interaction seems to be specific to $\mathrm{p} 107$, as $\mathrm{Rb}$ cannot repress the expression of the Hes 1 promoter in luciferase assays. To date, 


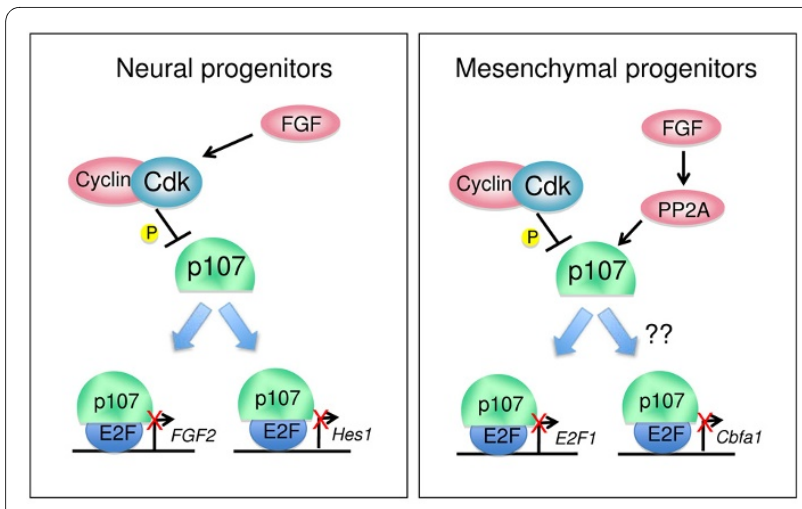

Figure 3 Proposed mechanisms for how p107 can control neuronal differentiation and endochondral bone formation. p107 can bind to E2Fs and potentially inhibit the transcription of Hes 1 and Fgf2, two genes involved in cell cycle control, survival, and cell fate decisions during neurogenesis (left panel). During endochondral bone formation in mesenchymal progenitors, FGF signaling can induce the direct binding and de-phosphorylation is p107 by PP2A, which then leads to p107-mediated repression of target genes. Although the direct targets of p107 in this context have yet to be identified, candidates such as E2F1 and Cbfa1 have both shown to be critical mediators of bone and chondrocyte development and are deregulated in the absence of p107 and p130 [138,139].

however, Hes 1 has yet to be proven to be a direct target of p107.

p107 may also be acting through the FGF growth factor signaling pathway to control the numbers of neural precursors in embryonic and adult brains (Figure 3). FGF is a critical factor to promote the proliferation and survival of neural precursors in the developing embryonic brain [109-111]. Like Hes1, the expression of Fgf2 (but not Fgf1, Fgfr1, or Fgfr2) is increased in neural progenitors of $p 107-$ deficient brains. Recently, p107 was shown to repress E2F3 activity at the promoter of $F g f 2$, an essential growth factor that modulates the population of neural precursors in the developing brain [112]. However, this model for p107 regulation of neural precursors does not explain why the increase in cell death observed in $1107^{-1-}$ brains, as increased FGF2 would be expected to promote survival. Therefore, the mechanisms driving apoptosis in p107\% progenitors may be independent of FGF2 signaling, and have yet to be identified.

The two examples in chondrocytes and neurons suggest a scenario in which FGF signaling can indirectly activate p107, which could then repress FGF signaling through direct promoter binding. Although this feedback loop between p107 and FGF has yet to be identified within one specific cell type, it suggests the potential for a complex regulatory system for $\mathrm{p} 107$ and growth signaling during development.

Recent studies have uncovered functions of p107 that overlap with $\mathrm{Rb}$ during development. Additional loss of $p 107$ shortened the lifespan of $\mathrm{Rb}^{-/}$embryos from birth to E14.5, and further increased the abnormal levels of proliferation and apoptosis that are present in the central nervous system and the ocular lens of $R b$-deficient embryos. Mutation of $p 107$ in an $R b$-deficient background also caused heart development defects that were not seen in the $R b$-deficient or $p 107$-deficient embryos alone. These heart defects are likely the result of blood vessel endothelium and endocardial cell proliferation in the absence of both $\mathrm{Rb}$ and $\mathrm{p} 107$. Additionally, the cerebellar architecture is severely disrupted in adult mice lacking both $\mathrm{Rb}$ and p107 in the dorsal mid-hind brain junction, and these mice exhibit impaired terminal differentiation and migration defects in granule cell precursors, in addition to increased granule cell apoptosis upon maturation [113]. While the mechanisms underlying these defects are unknown, it is possible that p107 may be acting as a co-factor for neuron-specific proteins such as NeuroD1 [114], a basic helix-loop-helix transcription factor known to be important in the development of mature neurons [115]. Thus, p107 can partially or fully compensate for the loss of $\mathrm{Rb}$ in several tissues during development.

\section{Tumor suppression}

$R b$ is mutated in a variety of sporadic and familiar human cancers, most notably in pediatric retinoblastoma and osteosarcoma. Mutations in p107 itself have not been observed in human tumors [116]. So far, the only observed deletion of p107 has been characterized in myeloproliferative disorders, where a large region of chromosome 20q containing up to 115 genes is deleted [116-118]. Despite the lack of mutation or deletion of p107 in human tumors, it still may play a role in tumorigenesis, as mutations in upstream regulators of the $\mathrm{Rb}$ family are common $[119,120]$. Inactivation of inhibitors such as p16, or activating mutations in Cyclin/Cdk complexes functionally inactivate $\mathrm{Rb}, \mathrm{p} 107$, and $\mathrm{p} 130$ by hyperphosphorylation, suggesting that inactivation of all three $\mathrm{Rb}$ family members is necessary for tumorigenesis in multiple settings [116]. This finding highlights the ability of the $\mathrm{Rb}$ family proteins to fulfill overlapping or redundant roles in a variety of cellular contexts.

It is clear that p107 is not a strong tumor suppressor by itself, as mice with mutations in p107 do not develop spontaneous tumors [102]. Since p107 and p130 have overlapping functions during development, it was postulated that compound mutation of both genes might give rise to tumors in mice. Studies of heterozygous $p 107^{+/-}$ $; p 130^{-/-}$and $p 107^{-/} ; p 130^{+/-}$mice revealed no spontaneous loss of either $p 107$ or $p 130$ allele and no obvious tumor phenotypes [121]. While cancer development in adult p107/ $;$; $130^{-/-}$mice has not been described, these studies suggest that p107 and p130 do not by themselves have tumor suppressor functions in the mouse. However, these 
observations do not exclude the possibility that p107 and/ or p130 may act as tumor suppressors in other contexts.

Interestingly, in the context of $R b$ loss, p107 can contribute some tumor suppressor functions within a cell (Table 2). Mice with mutations in $R b$ specifically in the epidermis develop epidermal hyperplasia and hyperkeratosis, however these mice do not develop tumors. Compound mutation of both $R b$ and p107 leads to papillomatous lesions within about 4 weeks; these lesions progress to squamous cell carcinomas shortly thereafter [122]. Just one wild-type allele of $p 107$ is enough to confer tumor suppression in this tissue [122,123]. Interestingly, one allele of $p 107$ is also sufficient to confer tumor suppression in studies of myeloproliferation in $R b$ family triple knock out mice $[124,125]$. The lung epithelium is also sensitive to $p 107$ loss in the absence of $R b . R b^{-/} ; p 107^{-}$ / lungs show increased proliferation compared to $R b^{-/}$ lungs, and double knockout lung epithelia develop adenomas or adenocarcinomas by 5 to 15 months of age. In contrast, $R b^{-/} ; p_{130} /$ lungs did not develop spontaneous tumors in this setting, indicating that p107, but not p130, can enhance $\mathrm{Rb}$ tumor suppressor activity in the lung epithelium [126].

While mutations of $R b$ in human patients predispose them to retinoblastoma and osteosarcoma, mice with mutations in $R b$ develop an entirely different spectrum of tumors; pituitary and thyroid tumors are the most common malignancies, but not retinoblastoma or osteosarcoma. This unexpected tumor spectrum in $R b$-deficient mice may be due to a functional compensation by p107 or p130. Indeed, some evidence exists for an upregulation of p107 protein in the absence of $\mathrm{Rb}$ in murine retinas, as discussed above [127]. A critical question, however, is whether p107 and p130 can suppress tumorigenesis similarly to $\mathrm{Rb}$, or whether they have different tumor suppressor capabilities altogether. p107 is expressed highly in retinal progenitors as they actively cycle during the latestages of embryonic development. p130, on the other hand, is only expressed at later postnatal stages of development in post-mitotic neurons $[45,127,128]$. Consistent with this observation, the combined loss of $R b$ and $p 107$ during embryogenesis resulted in massive retinal dysplasia, whereas compound deletion of $R b$ and $p 130$ had the same affect as deleting $R b$ alone [129]. Massive retinal dysplasia is also seen in adult chimeric mouse models lacking both $R b$ and $p 107$ in the retina $[129,130]$. These results pointed to a potential role for p107 in suppressing retinoblastoma in mice. The use of the Cre-lox technology and conditional mouse models revealed further insights into the tumor suppressor functions of p107. Retina-specific deletion of $R b$ on a $p 107^{-/}$background with Pax6a -Cre or Chx10-Cre mice leads to predominantly unilateral retinoblastomas with about $60 \%$ penetrance. Interestingly, $\mathrm{Rb}^{-/} ; \mathrm{p}^{-130^{-/}}$retinas in the same system develop bilateral tumors with half of the tumor latency $[131,132]$. The slower kinetics and partial pene-

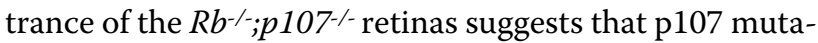
tion in this context is not always sufficient for tumorigenesis. A critical question that remains from these studies is whether the $R b^{-/ ;} ; 107^{-/-}$tumors still retain functional p130 [131]. Interestingly, mouse retinas with triple compound mutation of $R b, p 107$, and $p 53$ develop much more aggressive bilateral retinoblastoma in only a few months [44], suggesting that indeed, additional mutations are necessary for retinoblastoma formation in this context.

While it appears that $\mathrm{p} 130$ is a more potent tumor suppressor than p107 in retinal progenitors, p107 can still function as a tumor suppressor in specific cell types in the mouse retina. Studies of post-mitotic differentiated neurons of the inner nuclear layer (INL) of the retina showed that $\mathrm{Rb}$ expression was redundant with p130 [127]. In the absence of both $R b$ and $p 130$ in this cell type, presence of p107 was sufficient to prevent retinoblastoma. However, in the absence of even one copy in this context, $p 107$ was shown to be haploinsufficient for retinoblastoma development. Aggressive retinoblastomas arise from Chx10-Cre; $\mathrm{Rb}^{\text {lox }}$ /lox; $1130^{-/} ;$p107+/- horizontal neurons several weeks faster than retinoblastomas from Chx 10-Cre; Rblox/lox; p130-/ retinas [133]. Thus, it appears that in the INL of the retina, one copy of $p 107$ is not enough to prevent tumorigenesis, whereas in other contexts, such as in hematopoietic progenitors, one copy of p107 is strong enough to prevent tumorigenesis [124]. The mechanisms underlying these contextual differences have yet to be identified.

$R b$-heterozygosity results in retinoblastoma with $100 \%$ penetrance in humans but is not sufficient to cause retinoblastoma in mice. This difference in mice may be due to the ability for other family members, namely p107, to compensate for the loss of $\mathrm{Rb}$ in this context [127]. Interestingly, human retinal cells do not upregulate p107 in response to Rb loss, whereas mouse retinal cells do [127]. This difference may be due to different transcriptional regulation of p107 expression in mouse and human retinas; both mouse and human $p 107$ promoters contain two tandem E2F binding sites. The mouse promoter has a single point mutation in the proximal 3' E2F site that may affect the binding of E2Fs or other transcriptional machinery that is recruited there [27]. Alternatively, differences in the surrounding promoter regions may be able to explain why one species can upregulate $p 107$ in response to $\mathrm{Rb}$ loss in specific contexts, while the other cannot. These differences in $p 107$ transcriptional regulation may also be seen within the different tissues of the same organism. For example, if deregulation of the $\mathrm{Rb}$ pathway can be found in almost all human tumors, why, then, do $R b$-heterozygous patients primarily only develop 
Table 2: Summary of $p$ 107-deficient mouse models and their phenotypes.

\begin{tabular}{|c|c|c|c|c|}
\hline Genotype & Strategy & Lethality & Major Phenotypes & References \\
\hline p107-/-(Balb/c) & Germline & Viable & $\begin{array}{c}\text { Ectopic myeloid hyperplasia in the spleen and liver, severe } \\
\text { postnatal growth deficiency, fibroblasts and myoblasts } \\
\text { have increased cell cycle kinetics, decreased white adipose } \\
\text { tissue. }\end{array}$ & {$[99,100]$} \\
\hline p107-/-(mixed) & Germline & Viable & $\begin{array}{l}\text { No gross abnormalities, expanded neural progenitor pool } \\
\text { in the embryonic and adult brain. }\end{array}$ & {$[105,108]$} \\
\hline$R b+/-; p 107-/-$ & Germline & Viable & $\begin{array}{l}\text { Pituitary tumors, reduced viability and growth retardation } \\
\text { after birth until } \sim 3 \text { months of age, vaginal atresia (females). }\end{array}$ & {$[50]$} \\
\hline$R b+/-; p 107-/-$ & Chimera & Viable & $\begin{array}{l}\text { Pituitary glad tumors, adenocarcinoma of the caecum, } \\
\text { osteosarcoma, lymphosarcoma, occasional retinal } \\
\text { dysplasia but no retinoblastoma. }\end{array}$ & [130] \\
\hline$R b-/-; p 107-/-$ & Chimera & Viable & $\begin{array}{l}\text { Retinoblastoma development between } 1 \text { - } 3 \text { months of } \\
\text { age, adult mice obtained at low frequency, apoptosis in the } \\
\text { retina. }\end{array}$ & [130] \\
\hline$R b-/-; p 107-/-$ & Germline & Lethal E11.5 & Accelerated apoptosis in the liver and CNS. & [97] \\
\hline $\begin{array}{l}\text { Mox2Cre;Rblox/ } \\
\text { lox;p107-\% }\end{array}$ & $\begin{array}{l}\text { Conditional } \\
\text { (embryo) }\end{array}$ & $\begin{array}{l}\text { Lethal } \\
\text { E13.5-E14.5 }\end{array}$ & $\begin{array}{c}\text { Hyperproliferation of the CNS, lens, blood vessel } \\
\text { endothelial cells. Double-outlet right ventricle (DORV) } \\
\text { heart defect. }\end{array}$ & [142] \\
\hline p107-/-;p130-/- & Germline & Birth & $\begin{array}{l}\text { Hyperproliferation of chondrocytes, defective } \\
\text { endochondral bone development, increased epidermal } \\
\text { proliferation, decreased number of hair follicles, } \\
\text { developmental delay in whisker, hair, and tooth formation. }\end{array}$ & {$[101,102]$} \\
\hline $\begin{aligned} & R b-/-; p 107-/- \\
; & h I R B P p 53 D D\end{aligned}$ & Chimera & Viable & Retinoblastoma. & {$[44]$} \\
\hline $\begin{array}{l}\text { SPC- } \\
\text { rtTA;tetCre; } R b^{10 x /} \\
\text { lox;p107-- }\end{array}$ & $\begin{array}{l}\text { Conditional } \\
\text { (lung) }\end{array}$ & Viable & $\sim 70 \%$ of mice develop lung adenoma or adenocarcinoma. & [126] \\
\hline $\begin{array}{l}\text { K14Cre; } R b^{l o x /} \\
\text { lox;p107\%- }\end{array}$ & $\begin{array}{l}\text { Conditional } \\
\text { (skin) }\end{array}$ & Viable & Spontaneous squamous cell carcinomas. & [49] \\
\hline $\begin{array}{l}\text { NesCre;Rblox/ } \\
\text { lox;p107-/- }\end{array}$ & $\begin{array}{l}\text { Conditional } \\
\text { (retina) }\end{array}$ & Viable & Retinal dysplasia, high levels of apoptosis in the retina. & [129] \\
\hline 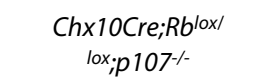 & $\begin{array}{l}\text { Conditional } \\
\text { (retina) }\end{array}$ & Viable & $\begin{array}{l}\text { Unilateral retinoblastoma, } 60 \% \text { penetrant, delayed onset } \\
\text { compared to } R b / p 53 / p 107 \text {. }\end{array}$ & [132] \\
\hline $\begin{array}{l}\text { Chx10Cre; } \mathrm{Rb}^{\text {lox/ }} \\
\text { lox;p53/ox//ox; } p 107^{-1}\end{array}$ & $\begin{array}{l}\text { Conditional } \\
\text { (retina) }\end{array}$ & Viable & Aggressive bilateral retinoblastoma, $100 \%$ penetrant. & {$[132,141]$} \\
\hline
\end{tabular}


Table 2: Summary of p107-deficient mouse models and their phenotypes. (Continued)

\begin{tabular}{|c|c|c|c|c|}
\hline 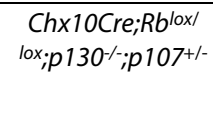 & $\begin{array}{c}\text { Conditional } \\
\text { (retina) }\end{array}$ & Viable & $\begin{array}{c}\text { Differentiated horizontal neurons of the Inner Nuclear } \\
\text { Layer re-enter the cell cycle and form metastatic } \\
\text { retinoblastoma. }\end{array}$ & [133] \\
\hline $\begin{array}{l}\text { Pax6a Cre; } R b^{\text {lox/ }} \\
\text { Iox;p107-1- }\end{array}$ & $\begin{array}{l}\text { Conditional } \\
\text { (retina) }\end{array}$ & Viable & $\begin{array}{c}\text { Unilateral retinoblastoma, } 60 \% \text { penetrant, delayed onset } \\
\text { compared to } \mathrm{Rb} / \mathrm{p} 130 .\end{array}$ & {$[131,143]$} \\
\hline $\begin{array}{l}\text { En2Cre; } \mathrm{Rb}^{\mathrm{Iox} /} \\
\text { Iox;p } 107^{-1}\end{array}$ & $\begin{array}{l}\text { Conditional } \\
\text { (dorsal mid- } \\
\text { hindbrain) }\end{array}$ & Viable & $\begin{array}{l}\text { Ataxia between P15 and P20, disorganized cerebellar } \\
\text { architecture, shrunken dendritic arborization, laminar } \\
\text { defects, hyperproliferation of granule cell precursors, and } \\
\text { granule cell death upon differentiation. }\end{array}$ & [113] \\
\hline $\begin{array}{l}\text { p107-/-;p27D51/ } \\
\text { D51 }\end{array}$ & Germline & Viable & $\begin{array}{l}\text { Chondrocyte hyperproliferation, defective chondrocyte } \\
\text { maturation, defective endochondral bone formation. }\end{array}$ & [103] \\
\hline Hes1-/-;p107-/- & Germline & Lethal E12.5 & $\begin{array}{c}\text { Embryonic lethality due to null Hes } 1 \text { mutation, restoration } \\
\text { of normal numbers of neural precursors in embryos and } \\
\text { adults. }\end{array}$ & [108] \\
\hline
\end{tabular}

a narrow spectrum of tumors, mainly retinoblastoma and osteosarcomas? This discrepancy may be explained by the fact that some tissues can upregulate p107 in response to $\mathrm{Rb}$ loss, whereas others cannot. Indeed upregulation of p107 is seen in several cell types upon $\mathrm{Rb}$ loss, including mouse retinal progenitors [127], keratinocytes [48], hepatocytes [36], and lung epithelial cells $[123,126]$. Interestingly, p107 seems to be the main Rb family member that can perform this function, as upregulation of $p 130$ is generally not seen in response to $\mathrm{Rb}$ or p107 or both [127].

\section{Conclusions}

To fully understand the tumor suppressor functions of $\mathrm{Rb}$ in human tumors, it is important to understand the functions of each of the family members, both individually and as a group. In particular, p107 functions in cell cycle control and tumor suppression have remained elusive.

During cell cycle progression, p107 function may be divided into two categories; those that require E2F and those that do not. ChIP-Seq for Rb family members and E2F family members in normal cells would shed light on the normal binding patterns of these proteins and may identify promoters that are regulated by individual $\mathrm{Rb}$ family members or by several at once. Expanding upon this, one could then compare the binding profiles of the $\mathrm{Rb}$ family members in normal cells to that of tumor cells, cells in different phases of the cell cycle, or cells from different tissues. p107 can also interact with several other key transcription factors such as Sp1, B-myb, c-myc, and Smad3. The significance of these interactions is not well understood, and several questions remain. For example, is $\mathrm{p} 107$ 's ability to regulate the cell cycle mainly exerted through E2F repression or can the interaction with other transcription factors also arrest the cell cycle independently of E2F $\alpha$ One way to answer these questions would be to take advantage of the fact that E2Fs bind different regions of p107 than do the other transcription factors.

Evidence for $\mathrm{p} 107$ function during S phase suggests that it may play a critical role outside of the control of G1. Rb and p130 have both been implicated in the control of G0 and G2 [134-136], so in some ways it is not surprising that p107 would also play a role outside of G1. However, evidence for an $\mathrm{Rb}$ family role during $\mathrm{S}$ phase has so far been scarce. It is striking that the highest protein levels of p107 are seen in S phase, a time when p107 should largely be inactivated by phosphorylation. What would be the advantage to having large pools of p107 sequestered within a cell after the transition into $\mathrm{S}$ phase? One hypothesis would be that in response to genotoxic stress, p107 would be rapidly dephosphorylated by PP2A and serve as a reservoir of a potent transcriptional repressor. Large pools of p107 may also be able to stabilize p27, which could inhibit the activity of the Cyclin/Cdk complexes. The identification of downstream targets of p107 in this context will shed light on the exact mechanism for this S-phase arrest.

It has yet to be determined whether p107 can serve as a tumor suppressor in the context of other mutations outside of the Rb pathway. To date, there have been no studies crossing mice with $p 107$ mutations to mice carrying mutations in other known cancer causing genes outside of the $\mathrm{Rb}$ pathway. Furthermore, no studies have examined whether $p 107$ mutation and DNA damaging agents can contribute to faster or more aggressive tumors. Future studies should clarify the specific contexts in 
which p107 can act as a tumor suppressor, with or without compound mutation of Rb.

Although much has been uncovered since the discovery of the $\mathrm{Rb}$ family, the complexities in functional overlap, regulation, and tumor suppressor abilities of each of the $\mathrm{Rb}$ family members is only just beginning to be explored. The use of transgenic, knock-in, and knock-out mouse studies, as well as in vitro cell culture systems will be critical to increase our understanding of the role of these genes during multiple cellular functions, and these techniques will continue to reveal the subtle and distinct ways in which these proteins can interact with each other as well as the hundreds of other proteins known to associate with them. More analysis of how the $\mathrm{Rb}$ family normally functions is needed to understand their functions within a single cell, in addition to their tumor suppressor capabilities.

\section{List of abbreviations}

Rb: Retinoblastoma; Cdk: Cyclin-dependent kinase; HDAC: histone deacetylase; DHFR: dihydrofolate reductase; BMP: bone morphogenetic protein; FGF: fibroblast growth factor; VZ: ventricular zone; ChIP: chromatin immunoprecipitation.

\section{Competing interests}

The authors declare that they have no competing interests.

\section{Authors' contributions}

SW and JS designed and wrote the manuscript together. Both authors have read and approved the final manuscript.

\section{Acknowledgements}

The authors would like to thank Jamie Conklin, Louis Saddic, Ruth Tennen, and Deborah Burkhart for thoughtful discussions and critical reading of the manuscript. This work was supported by the Lucile Packard Foundation for Children's Health and NIH-NCI RO1 CA114102 (J.S.), as well as a fellowship from the National Science Foundation (S.W.).

\section{Author Details}

'Departments of Pediatrics and Genetics, Stanford Medical School, Stanford, CA 94305, USA and 2Program in Cancer Biology, Stanford Medical School, Stanford, CA, 94305, USA

Received: 12 March 2010 Accepted: 2 April 2010

Published: 2 April 2010

\section{References}

1. Dryja TP, Friend S, Weinberg RA: Genetic sequences that predispose to retinoblastoma and osteosarcoma. Symp Fundam Cancer Res 1986, 39:115-119.

2. Friend SH, Bernards R, Rogelj S, Weinberg RA, Rapaport JM, Albert DM, Dryja TP: A human DNA segment with properties of the gene that predisposes to retinoblastoma and osteosarcoma. Nature 1986, 323:643-646.

3. Lee WH, Bookstein R, Hong F, Young LJ, Shew JY, Lee EY: Human retinoblastoma susceptibility gene: cloning, identification, and sequence. Science 1987, 235:1394-1399.

4. Lee WH, Shew JY, Hong FD, Sery TW, Donoso LA, Young $\sqcup$, Bookstein R, Lee EY: The retinoblastoma susceptibility gene encodes a nuclear phosphoprotein associated with DNA binding activity. Nature 1987, 329:642-645.
5. Burkhart DL, Sage J: Cellular mechanisms of tumour suppression by the retinoblastoma gene. Nat Rev Cancer 2008, 8:671-682.

6. Whyte P, Buchkovich KJ, Horowitz JM, Friend SH, Raybuck M, Weinberg RA, Harlow E: Association between an oncogene and an anti-oncogene: the adenovirus E1 A proteins bind to the retinoblastoma gene product. Nature 1988, 334:124-129.

7. DeCaprio JA, Ludlow JW, Figge J, Shew JY, Huang CM, Lee WH, Marsilio E, Paucha E, Livingston DM: SV40 large tumor antigen forms a specific complex with the product of the retinoblastoma susceptibility gene. Cell 1988, 54:275-283.

8. Horowitz JM, Yandell DW, Park SH, Canning S, Whyte P, Buchkovich K, Harlow E, Weinberg RA, Dryja TP: Point mutational inactivation of the retinoblastoma antioncogene. Science 1989, 243:937-940.

9. Dyson N, Howley PM, Munger K, Harlow E: The human papilloma virus$16 \mathrm{E} 7$ oncoprotein is able to bind to the retinoblastoma gene product. Science 1989, 243:934-937.

10. Munger K, Werness BA, Dyson N, Phelps WC, Harlow E, Howley PM: Complex formation of human papillomavirus E7 proteins with the retinoblastoma tumor suppressor gene product. EMBO J 1989, 8:4099-4105.

11. Ewen ME, Ludlow JW, Marsilio E, DeCaprio JA, Millikan RC, Cheng SH, Paucha E, Livingston DM: An N-terminal transformation-governing sequence of SV40 large T antigen contributes to the binding of both p110Rb and a second cellular protein, p120. Cell 1989, 58:257-267.

12. Dyson N, Buchkovich K, Whyte P, Harlow E: The cellular 107K protein that binds to adenovirus E1A also associates with the large $T$ antigens of SV40 and JC virus. Cell 1989, 58:249-255.

13. Harlow E, Whyte P, Franza BR Jr, Schley C: Association of adenovirus early-region 1A proteins with cellular polypeptides. Mol Cell Biol 1986, 6:1579-1589.

14. Claudio PP, Tonini T, Giordano A: The retinoblastoma family: twins or distant cousins? Genome Biol 2002, 3:reviews3012.

15. Fang SC, Umen JG: A suppressor screen in chlamydomonas identifies novel components of the retinoblastoma tumor suppressor pathway. Genetics 2008, 178:1295-1310

16. Cooper K: Rb, whi it's not just for metazoans anymore. Oncogene 2006, 25:5228-5232

17. Costanzo M, Nishikawa JL, Tang X, Millman JS, Schub O, Breitkreuz K Dewar D, Rupes I, Andrews B, Tyers M: CDK activity antagonizes Whi5, an inhibitor of G1/S transcription in yeast. Cell 2004, 117:899-913.

18. De Bruin RA, McDonald WH, Kalashnikova TI, Yates J, Wittenberg C: Cln3 activates $\mathrm{G1}$-specific transcription via phosphorylation of the SBF bound repressor Whi5. Cell 2004, 117:887-898.

19. Sabelli PA, Larkins BA: Grasses like mammals? Redundancy and compensatory regulation within the retinoblastoma protein family. Cell Cycle 2006, 5:352-355.

20. Lendvai A, Pettko-Szandtner A, Csordas-Toth E, Miskolczi P, Horvath GV Gyorgyey J, Dudits D: Dicot and monocot plants differ in retinoblastoma-related protein subfamilies. J Exp Bot 2007 , 58:1663-1675

21. Lu X, Horvitz HR: lin-35 and lin-53, two genes that antagonize a $C$. elegans Ras pathway, encode proteins similar to $\mathrm{Rb}$ and its binding protein RbAp48. Cell 1998, 95:981-991.

22. Stevaux O, Dimova D, Frolov MV, Taylor-Harding B, Morris E, Dyson N: Distinct mechanisms of E2F regulation by Drosophila RBF1 and RBF2. EMBO / 2002, 21:4927-4937.

23. Heuvel $\mathrm{S}$ van den, Dyson NJ: Conserved functions of the $\mathrm{pRB}$ and E2F families. Nat Rev Mol Cell Biol 2008, 9:713-724.

24. Du W, Dyson N: The role of RBF in the introduction of $\mathrm{G} 1$ regulation during Drosophila embryogenesis. EMBO J 1999, 18:916-925.

25. Dimova DK, Stevaux O, Frolov MV, Dyson NJ: Cell cycle-dependent and cell cycle-independent control of transcription by the Drosophila E2F/ RB pathway. Genes Dev 2003, 17:2308-2320.

26. Smith EJ, Leone G, Nevins JR: Distinct mechanisms control the accumulation of the Rb-related $\mathrm{p} 107$ and $\mathrm{p} 130$ proteins during cell growth. Cell Growth Differ 1998, 9:297-303.

27. Zhu L, Xie E, Chang LS: Differential roles of two tandem E2F sites in repression of the human $\mathrm{p} 107$ promoter by retinoblastoma and $\mathrm{p} 107$ proteins. Mol Cell Biol 1995, 15:3552-3562.

28. Lynch M, Conery JS: The evolutionary fate and consequences of duplicate genes. Science 2000, 290:1151-1155. 
29. Nowak MA, Boerlijst MC, Cooke J, Smith JM: Evolution of genetic redundancy. Nature 1997, 388:167-171.

30. Force A, Lynch M, Pickett FB, Amores A, Yan YL, Postlethwait J: Preservation of duplicate genes by complementary, degenerative mutations. Genetics 1999, 151:1531-1545.

31. Ewen ME, Xing YG, Lawrence JB, Livingston DM: Molecular cloning, chromosomal mapping, and expression of the CDNA for p107, a retinoblastoma gene product-related protein. Cell 1991, 66:1155-1164.

32. Kiess M, Gill RM, Hamel PA: Expression and activity of the retinoblastoma protein (pRB)-family proteins, p107 and p130, during L6 myoblast differentiation. Cell Growth Differ 1995, 6:1287-1298.

33. Beijersbergen RL, Carlee L, Kerkhoven RM, Bernards R: Regulation of the retinoblastoma protein-related $\mathrm{p} 107$ by $\mathrm{G} 1$ cyclin complexes. Genes Dev 1995, 9:1340-1353.

34. Mayol X, Garriga J, Grana X: Cell cycle-dependent phosphorylation of the retinoblastoma-related protein p130. Oncogene 1995, 11:801-808.

35. Mayol X, Garriga J, Grana X: G1 cyclin/CDK-independent phosphorylation and accumulation of $\mathrm{p} 130$ during the transition from G1 to G0 lead to its association with E2F-4. Oncogene 1996, 13:237-246.

36. Burkhart DL, Viatour P, Ho VM, Sage J: GFP reporter mice for the retinoblastoma-related cell cycle regulator p107. Cell Cycle 2008, 7:2544-2552.

37. Garriga J, Limon A, Mayol X, Rane SG, Albrecht JH, Reddy EP, Andres V, Grana X: Differential regulation of the retinoblastoma family of proteins during cell proliferation and differentiation. Biochem J 1998, 333(Pt 3):645-654.

38. Verona R, Moberg K, Estes S, Starz M, Vernon JP, Lees JA: E2F activity is regulated by cell cycle-dependent changes in subcellular localization. Mol Cell Biol 1997, 17:7268-7282.

39. Puri PL, Cimino L, Fulco M, Zimmerman C, La Thangue NB, Giordano A, Graessmann A, Levrero M: Regulation of E2F4 mitogenic activity during terminal differentiation by its heterodimerization partners for nuclear translocation. Cancer Res 1998, 58:1325-1331.

40. Kennedy BK, Barbie DA, Classon M, Dyson N, Harlow E: Nuclear organization of DNA replication in primary mammalian cells. Genes Dev 2000, 14:2855-2868

41. Zini N, Trimarchi C, Claudio PP, Stiegler P, Marinelli F, Maltarello MC, La Sala D, De Falco G, Russo G, Ammirati G, et al.: pRb2/p130 and p107 control cell growth by multiple strategies and in association with different compartments within the nucleus. J Cell Physiol 2001, 189:34-44.

42. Sage J, Miller AL, Perez-Mancera PA, Wysocki JM, Jacks T: Acute mutation of retinoblastoma gene function is sufficient for cell cycle re-entry. Nature 2003, 424:223-228.

43. Schneider JW, Gu W, Zhu L, Mahdavi V, Nadal-Ginard B: Reversal of terminal differentiation mediated by p107 in Rb-/- muscle cells. Science 1994, 264:1467-1471.

44. Robanus-Maandag E, Dekker M, Valk M van der, Carrozza ML, Jeanny JC, Dannenberg JH, Berns A, te Riele $\mathrm{H}$ : p107 is a suppressor of retinoblastoma development in pRb-deficient mice. Genes Dev 1998, 12:1599-1609

45. Hurford RK Jr, Cobrinik D, Lee MH, Dyson N: pRB and p107/p130 are required for the regulated expression of different sets of $\mathrm{E} 2 \mathrm{~F}$ responsive genes. Genes Dev 1997, 11:1447-1463.

46. Callaghan DA, Dong L, Callaghan SM, Hou YX, Dagnino L, Slack RS: Neural precursor cells differentiating in the absence of $\mathrm{Rb}$ exhibit delayed terminal mitosis and deregulated E2F 1 and 3 activity. Dev Biol 1999, 207:257-270.

47. Mayhew CN, Bosco EE, Fox SR, Okaya T, Tarapore P, Schwemberger SJ, Babcock GF, Lentsch AB, Fukasawa K, Knudsen ES: Liver-specific pRB loss results in ectopic cell cycle entry and aberrant ploidy. Cancer Res 2005, 65:4568-4577

48. Lara MF, Garcia-Escudero R, Ruiz S, Santos M, Moral M, Martinez-Cruz AB, Segrelles C, Lorz C, Paramio JM: Gene profiling approaches help to define the specific functions of retinoblastoma family in epidermis. Mol Carcinog 2008, 47:209-221

49. Ruiz S, Santos M, Segrelles C, Leis H, Jorcano JL, Berns A, Paramio JM, Vooijs $\mathrm{M}:$ Unique and overlapping functions of $\mathrm{pRb}$ and $\mathrm{p} 107$ in the control of proliferation and differentiation in epidermis. Development 2004, 131:2737-2748

50. Lee MH, Williams BO, Mulligan G, Mukai S, Bronson RT, Dyson N, Harlow E, Jacks T: Targeted disruption of p107: functional overlap between $\mathrm{p} 107$ and Rb. Genes Dev 1996, 10:1621-1632.
51. Cao L, Faha B, Dembski M, Tsai LH, Harlow E, Dyson N: Independent binding of the retinoblastoma protein and p107 to the transcription factor E2F. Nature 1992, 355:176-179.

52. Zhu L, Heuvel $\mathrm{S}$ van den, Helin K, Fattaey A, Ewen M, Livingston D, Dyson $\mathrm{N}$, Harlow E: Inhibition of cell proliferation by $\mathrm{p} 107$, a relative of the retinoblastoma protein. Genes Dev 1993, 7:1111-1125.

53. Chellappan SP, Hiebert S, Mudryj M, Horowitz JM, Nevins JR: The E2F transcription factor is a cellular target for the RB protein. Cell 1991, 65:1053-1061.

54. Classon M, Dyson N: p107 and p130: versatile proteins with interesting pockets. Exp Cell Res 2001, 264:135-147.

55. Xiao ZX, Ginsberg D, Ewen M, Livingston DM: Regulation of the retinoblastoma protein-related protein $\mathrm{p} 107$ by $\mathrm{G} 1$ cyclin-associated kinases. Proc Natl Acad Sci USA 1996, 93:4633-4637.

56. Balciunaite E, Spektor A, Lents NH, Cam H, Te Riele H, Scime A, Rudnick MA, Young R, Dynlacht BD: Pocket protein complexes are recruited to distinct targets in quiescent and proliferating cells. Mol Cell Biol 2005, 25:8166-8178

57. Garriga J, Jayaraman AL, Limon A, Jayadeva G, Sotillo E, Truongcao M, Patsialou A, Wadzinski BE, Grana X: A dynamic equilibrium between CDKs and PP2A modulates phosphorylation of pRB, p107 and p130. Cell Cycle 2004, 3:1320-1330

58. Kolupaeva V, Laplantine E, Basilico C: PP2A-mediated dephosphorylation of p107 plays a critical role in chondrocyte cell cycle arrest by FGF. PLoS One 2008, 3:e3447.

59. Voorhoeve PM, Hijmans EM, Bernards R: Functional interaction between a novel protein phosphatase $2 \mathrm{~A}$ regulatory subunit, PR59, and the retinoblastoma-related p107 protein. Oncogene 1999, 18:515-524.

60. Magnaghi-Jaulin L, Groisman R, Naguibneva I, Robin P, Lorain S, Le Villain $J P$, Troalen F, Trouche D, Harel-Bellan A: Retinoblastoma protein represses transcription by recruiting a histone deacetylase. Nature 1998, 391:601-605

61. Zhu WG, Seno JD, Beck BD, Dynlacht JR: Translocation of MRE11 from the nucleus to the cytoplasm as a mechanism of radiosensitization by heat. Radiat Res 2001, 156:95-102.

62. Vandel L, Nicolas E, Vaute O, Ferreira R, Ait-Si-Ali S, Trouche D: Transcriptional repression by the retinoblastoma protein through the recruitment of a histone methyltransferase. Mol Cell Biol 2001 21:6484-6494

63. Ferreira R, Magnaghi-Jaulin L, Robin P, Harel-Bellan A, Trouche D: The three members of the pocket proteins family share the ability to repress E2F activity through recruitment of a histone deacetylase. Proc Natl Acad Sci USA 1998, 95:10493-10498.

64. Strober BE, Dunaief JL, Guha, Goff SP: Functional interactions between the hBRM/hBRG1 transcriptional activators and the pRB family of proteins. Mol Cell Biol 1996, 16:1576-1583.

65. Yoshimoto T, Boehm M, Olive M, Crook MF, San H, Langenickel T, Nabel EG: The arginine methyltransferase PRMT2 binds RB and regulates E2F function. Exp Cell Res 2006, 312:2040-2053.

66. Brehm A, Miska EA, McCance DJ, Reid JL, Bannister AJ, Kouzarides T: Retinoblastoma protein recruits histone deacetylase to repress transcription. Nature 1998, 391:597-601

67. Ferreira R, Naguibneva I, Mathieu M, Ait-Si-Ali S, Robin P, Pritchard LL, Harel-Bellan A: Cell cycle-dependent recruitment of HDAC-1 correlates with deacetylation of histone $\mathrm{H} 4$ on an $\mathrm{Rb}-\mathrm{E} 2 \mathrm{~F}$ target promoter. $E M B O$ Rep 2001, 2:794-799.

68. Dick FA: Structure-function analysis of the retinoblastoma tumor suppressor protein - is the whole a sum of its parts? Cell Div 2007, 2:26.

69. Ross JF, Liu X, Dynlacht BD: Mechanism of transcriptional repression of E2F by the retinoblastoma tumor suppressor protein. Mol Cell 1999, 3:195-205

70. Lee EY, Cam H, Ziebold U, Rayman JB, Lees JA, Dynlacht BD: E2F4 loss suppresses tumorigenesis in $\mathrm{Rb}$ mutant mice. Cancer Cell 2002, 2:463-472

71. Ginsberg D, Vairo G, Chittenden T, Xiao ZX, Xu G, Wydner KL, DeCaprio JA, Lawrence JB, Livingston DM: E2F-4, a new member of the E2F transcription factor family, interacts with p107. Genes Dev 1994 8:2665-2679.

72. Lindeman GJ, Gaubatz S, Livingston DM, Ginsberg D: The subcellular localization of E2F-4 is cell-cycle dependent. Proc Natl Acad Sci USA 1997, 94:5095-5100. 
73. Vairo G, Livingston DM, Ginsberg D: Functional interaction between E2F4 and p130: evidence for distinct mechanisms underlying growth suppression by different retinoblastoma protein family members. Genes Dev 1995, 9:869-881.

74. Dyson N, Dembski M, Fattaey A, Ngwu C, Ewen M, Helin K: Analysis of p107-associated proteins: 107 associates with a form of E2F that differs from pRB-associated E2F-1. J Virol 1993, 67:7641-7647.

75. Moberg K, Starz MA, Lees JA: E2F-4 switches from p130 to p107 and pRB in response to cell cycle reentry. Mol Cell Biol 1996, 16:1436-1449.

76. Blais A, Dynlacht BD: E2F-associated chromatin modifiers and cell cycle control. Curr Opin Cell Biol 2007, 19:658-662.

77. Chen CR, Kang Y, Siegel PM, Massague J: E2F4/5 and p107 as Smad cofactors linking the TGFbeta receptor to c-myc repression. Cell 2002, 110:19-32.

78. Rodier G, Makris C, Coulombe P, Scime A, Nakayama K, Nakayama KI, Meloche S: p107 inhibits G1 to S phase progression by downregulating expression of the F-box protein Skp2. J Cell Biol 2005, 168:55-66.

79. Hwang HC, Clurman BE: Cyclin E in normal and neoplastic cell cycles. Oncogene 2005, 24:2776-2786

80. Jiang H, Karnezis AN, Tao M, Guida PM, Zhu L: pRB and p107 have distinct effects when expressed in pRB-deficient tumor cells at physiologically relevant levels. Oncogene 2000, 19:3878-3887.

81. Kondo T, Higashi H, Nishizawa H, Ishikawa S, Ashizawa S, Yamada M, Makita Z, Koike T, Hatakeyama M: Involvement of pRB-related p107 protein in the inhibition of $S$ phase progression in response to genotoxic stress. J Biol Chem 2001, 276:17559-17567.

82. Voorhoeve PM, Watson RJ, Farlie PG, Bernards R, Lam EW: Rapid dephosphorylation of p107 following UV irradiation. Oncogene 1999, 18:679-688

83. Zhu L, Harlow E, Dynlacht BD: p107 uses a p21CIP1-related domain to bind cyclin/cdk2 and regulate interactions with E2F. Genes Dev 1995, 9:1740-1752.

84. Ewen ME, Faha B, Harlow E, Livingston DM: Interaction of p107 with cyclin A independent of complex formation with viral oncoproteins. Science 1992, 255:85-87.

85. Faha B, Ewen ME, Tsai LH, Livingston DM, Harlow E: Interaction between human cyclin A and adenovirus E1A-associated p107 protein. Science 1992, 255:87-90.

86. Lees E, Faha B, Dulic V, Reed SI, Harlow E: Cyclin E/cdk2 and cyclin A/cdk2 kinases associate with $\mathrm{p} 107$ and $\mathrm{E} 2 \mathrm{~F}$ in a temporally distinct manner. Genes Dev 1992, 6:1874-1885.

87. Zhu L, Enders G, Lees JA, Beijersbergen RL, Bernards R, Harlow E: The pRBrelated protein 107 contains two growth suppression domains: independent interactions with $\mathrm{E} 2 \mathrm{~F}$ and cyclin/cdk complexes. EMBO J 1995, 14:1904-1913

88. Castano E, Kleyner Y, Dynlacht BD: Dual cyclin-binding domains are required for p107 to function as a kinase inhibitor. Mol Cell Biol 1998, 18:5380-5391.

89. Woo MS, Sanchez I, Dynlacht BD: p130 and p107 use a conserved domain to inhibit cellular cyclin-dependent kinase activity. Mol Cell Biol 1997, 17:3566-3579.

90. Bienvenu F, Jirawatnotai S, Elias JE, Meyer CA, Mizeracka K, Marson A Frampton GM, Cole MF, Odom DT, Odajima J, et al:: Transcriptional role of cyclin D1 in development revealed by a genetic-proteomic screen. Nature 2010, 463:374-378.

91. Datta PK, Raychaudhuri P, Bagchi S: Association of p107 with Sp1: genetically separable regions of $\mathrm{p} 107$ are involved in regulation of E2Fand Sp1-dependent transcription. Mol Cell Biol 1995, 15:5444-5452.

92. Parakati R, DiMario JX: Dynamic transcriptional regulatory complexes, including E2F4, p107, p130, and Sp1, control fibroblast growth factor receptor 1 gene expression during myogenesis. J Biol Chem 2005, 280:21284-21294.

93. Joaquin M, Bessa M, Saville MK, Watson RJ: B-Myb overcomes a p107mediated cell proliferation block by interacting with an $\mathrm{N}$-terminal domain of p107. Oncogene 2002, 21:7923-7932.

94. Beijersbergen RL, Hijmans EM, Zhu L, Bernards R: Interaction of c-Myc with the pRb-related protein p107 results in inhibition of c-Mycmediated transactivation. EMBO J 1994, 13:4080-4086.

95. Gu W, Bhatia K, Magrath IT, Dang CV, Dalla-Favera R: Binding and suppression of the Myc transcriptional activation domain by $\mathrm{p} 107$. Science 1994, 264:251-254
96. De Falco G, Comes F, Simone C: pRb: master of differentiation. Coupling irreversible cell cycle withdrawal with induction of muscle-specific transcription. Oncogene 2006, 25:5244-5249.

97. Lipinski MM, Jacks T: The retinoblastoma gene family in differentiation and development. Oncogene 1999, 18:7873-7882.

98. Nguyen DX, McCance DJ: Role of the retinoblastoma tumor suppressor protein in cellular differentiation. J Cell Biochem 2005, 94:870-879.

99. LeCouter JE, Kablar B, Hardy WR, Ying C, Megeney LA, May LL, Rudnicki MA: Strain-dependent myeloid hyperplasia, growth deficiency, and accelerated cell cycle in mice lacking the Rb-related p107 gene. Mol Cell Biol 1998, 18:7455-7465.

100. Scime A, Grenier G, Huh MS, Gillespie MA, Bevilacqua L, Harper ME, Rudnicki MA: $\mathrm{Rb}$ and $\mathrm{p} 107$ regulate preadipocyte differentiation into white versus brown fat through repression of PGC-1alpha. Cell Metab 2005, 2:283-295

101. Ruiz S, Segrelles C, Bravo A, Santos M, Perez P, Leis H, Jorcano JL, Paramio $\mathrm{JM}$ : Abnormal epidermal differentiation and impaired epithelialmesenchymal tissue interactions in mice lacking the retinoblastoma relatives p107 and p130. Development 2003, 130:2341-2353.

102. Cobrinik D, Lee MH, Hannon G, Mulligan G, Bronson RT, Dyson N, Harlow E, Beach D, Weinberg RA, Jacks T: Shared role of the pRB-related p130 and p107 proteins in limb development. Genes Dev 1996, 10:1633-1644.

103. Yeh N, Miller JP, Gaur T, Capellini TD, Nikolich-Zugich J, de la Hoz C, Selleri L, Bromage TG, van Wijnen AJ, Stein GS, et al:: Cooperation between p27 and p107 during endochondral ossification suggests a genetic pathway controlled by p27 and p130. Mol Cell Biol 2007, 27:5161-5171.

104. Laplantine E, Rossi F, Sahni M, Basilico C, Cobrinik D: FGF signaling targets the $\mathrm{pRb}$-related $\mathrm{p} 107$ and $\mathrm{p} 130$ proteins to induce chondrocyte growth arrest. J Cell Biol 2002, 158:741-750.

105. Vanderluit JL, Ferguson KL, Nikoletopoulou V, Parker M, Ruzhynsky V, Alexson T, McNamara SM, Park DS, Rudnicki M, Slack RS: p107 regulates neural precursor cells in the mammalian brain. J Cell Biol 2004, 166:853-863.

106. Jiang Z, Zacksenhaus E, Gallie BL, Phillips RA: The retinoblastoma gene family is differentially expressed during embryogenesis. Oncogene 1997, 14:1789-1797.

107. Yoshikawa K: Cell cycle regulators in neural stem cells and postmitotic neurons. Neurosci Res 2000, 37:1-14.

108. Vanderluit J, Wylie CA, McClellan KA, Ghanem N, Fortin A, Callaghan S, MacLaurin JG, Park DS, Slack RS: The Retinoblastoma family member p107 regulates the rate of progenitor commitment to a neuronal fate. J Cell Biol 2007, 178:129-139.

109. Raballo R, Rhee J, Lyn-Cook R, Leckman JF, Schwartz ML, Vaccarino FM: Basic fibroblast growth factor (Fgf2) is necessary for cell proliferation and neurogenesis in the developing cerebral cortex. J Neurosci 2000, 20:5012-5023.

110. Gritti A, Parati EA, Cova L, Frolichsthal P, Galli R, Wanke E, Faravelli L, Morassutti DJ, Roisen F, Nickel DD, Vescovi AL: Multipotential stem cells from the adult mouse brain proliferate and self-renew in response to basic fibroblast growth factor. J Neurosci 1996, 16:1091-1100.

111. Kilpatrick TJ, Bartlett PF: Cloned multipotential precursors from the mouse cerebrum require FGF-2, whereas glial restricted precursors are stimulated with either FGF-2 or EGF. J Neurosci 1995, 15:3653-3661.

112. McClellan KA, Vanderluit JL, Julian LM, Andrusiak MG, Dugal-Tessier D, Park DS, Slack RS: The p107/E2F pathway regulates fibroblast growth factor 2 responsiveness in neural precursor cells. Mol Cell Biol 2009, 29:4701-4713.

113. Marino S, Hoogervoorst D, Brandner S, Berns A: Rb and $\mathrm{p} 107$ are required for normal cerebellar development and granule cell survival but not for Purkinje cell persistence. Development 2003, 130:3359-3368.

114. Batsche E, Moschopoulos P, Desroches J, Bilodeau S, Drouin J: Retinoblastoma and the related pocket protein $\mathrm{p} 107$ act as coactivators of NeuroD1 to enhance gene transcription. $J$ Biol Chem 2005, 280:16088-16095.

115. Gao Z, Ure K, Ables JL, Lagace DC, Nave KA, Goebbels S, Eisch AJ, Hsieh J: Neurod 1 is essential for the survival and maturation of adult-born neurons. Nat Neurosci 2009, 12:1090-1092.

116. Beroukhim R, Mermel CH, Porter D, Wei G, Raychaudhuri S, Donovan J, Barretina J, Boehm JS, Dobson J, Urashima M, et al.: The landscape of somatic copy-number alteration across human cancers. Nature 2010, 463:899-905. 
117. Asimakopoulos FA, White NJ, Nacheva E, Green AR: Molecular analysis of chromosome $20 \mathrm{q}$ deletions associated with myeloproliferative disorders and myelodysplastic syndromes. Blood 1994, 84:3086-3094.

118. Ichimura K, Hanafusa H, Takimoto H, Ohgama Y, Akagi T, Shimizu K: Structure of the human retinoblastoma-related p107 gene and its intragenic deletion in a B-cell lymphoma cell line. Gene 2000, 251:37-43.

119. Pei $X H$, Xiong Y: Biochemical and cellular mechanisms of mammalian CDK inhibitors: a few unresolved issues. Oncogene 2005, 24:2787-2795.

120. Canepa ET, Scassa ME, Ceruti JM, Marazita MC, Carcagno AL, Sirkin PF, Ogara MF: INK4 proteins, a family of mammalian CDK inhibitors with novel biological functions. IUBMB Life 2007, 59:419-426.

121. Mulligan $G$, Jacks $T$ : The retinoblastoma gene family: cousins with overlapping interests. Trends Genet 1998, 14:223-229.

122. Lara MF, Santos M, Ruiz S, Segrelles C, Moral M, Martinez-Cruz AB, Hernandez P, Martinez-Palacio J, Lorz C, Garcia-Escudero R, Paramio JM: p107 acts as a tumor suppressor in pRb-deficient epidermis. Mol Carcinog 2008, 47:105-113.

123. Santos M, Ruiz S, Lara MF, Segrelles C, Moral M, Martinez-Cruz AB, Ballestin C, Lorz C, Garcia-Escudero R, Paramio JM: Susceptibility of pRb-deficient epidermis to chemical skin carcinogenesis is dependent on the p107 allele dosage. Mol Carcinog 2008, 47:815-821.

124. Viatour P, Somervaille TC, Venkatasubrahmanyam S, Kogan S, McLaughlin ME, Weissman IL, Butte AJ, Passegue E, Sage J: Hematopoietic stem cell quiescence is maintained by compound contributions of the retinoblastoma gene family. Cell Stem Cell 2008, 3:416-428.

125. Macpherson D: Insights from mouse models into human retinoblastoma. Cell Div 2008, 3:9

126. Simpson DS, Mason-Richie NA, Gettler CA, Wikenheiser-Brokamp KA Retinoblastoma family proteins have distinct functions in pulmonary epithelial cells in vivo critical for suppressing cell growth and tumorigenesis. Cancer Res 2009, 69:8733-8741.

127. Donovan SL, Schweers B, Martins R, Johnson D, Dyer MA: Compensation by tumor suppressor genes during retinal development in mice and humans. BMC Biol 2006, 4:14.

128. Kwartz AJ, Henson DB, Harper RA, Spencer AF, McLeod D: The effectiveness of the Heidelberg Retina Tomograph and laser diagnostic glaucoma scanning system (GDx) in detecting and monitoring glaucoma. Health Technol Assess 2005, 9:1-132

129. MacPherson D, Sage J, Kim T, Ho D, McLaughlin ME, Jacks T: Cell typespecific effects of Rb deletion in the murine retina. Genes Dev 2004, 18:1681-1694

130. Dannenberg JH, Schuijff L, Dekker M, Valk M van der, te Riele H: Tissuespecific tumor suppressor activity of retinoblastoma gene homologs p107 and p130. Genes Dev 2004, 18:2952-2962.

131. MacPherson D, Conkrite K, Tam M, Mukai S, Mu D, Jacks T: Murine bilateral retinoblastoma exhibiting rapid-onset, metastatic progression and N-myc gene amplification. EMBO J 2007, 26:784-794.

132. Johnson DA, Zhang J, Frase S, Wilson M, Rodriguez-Galindo C, Dyer MA: Neuronal differentiation and synaptogenesis in retinoblastoma. Cancer Res 2007, 67:2701-2711.

133. Ajioka I, Martins RA, Bayazitov IT, Donovan S, Johnson DA, Frase S, Cicero SA, Boyd K, Zakharenko SS, Dyer MA: Differentiated horizontal interneurons clonally expand to form metastatic retinoblastoma in mice. Cell 2007, 131:378-390.

134. Plesca D, Crosby ME, Gupta D, Almasan A: E2F4 function in G2: maintaining $\mathrm{G} 2$-arrest to prevent mitotic entry with damaged DNA. Cell Cycle 2007, 6:1147-1152

135. Stark GR, Taylor WR: Control of the G2/M transition. Mol Biotechnol 2006, 32:227-248

136. Sun A, Bagella L, Tutton S, Romano G, Giordano A: From G0 to S phase: a view of the roles played by the retinoblastoma $(\mathrm{Rb})$ family members in the Rb-E2F pathway. J Cell Biochem 2007, 102:1400-1404

137. Sol Genomics Network [http://solgenomics.net/]

138. Scheijen B, Bronk M, Meer T van der, Bernards R: Constitutive E2F1 overexpression delays endochondral bone formation by inhibiting chondrocyte differentiation. Mol Cell Biol 2003, 23:3656-3668.

139. Rossi F, MacLean HE, Yuan W, Francis RO, Semenova E, Lin CS, Kronenberg HM, Cobrinik D: $\mathrm{p} 107$ and $\mathrm{p} 130$ Coordinately regulate proliferation, Cbfa1 expression, and hypertrophic differentiation during endochondral bone development. Dev Biol 2002, 247:271-285.
140. Shirodkar S, Ewen M, DeCaprio JA, Morgan J, Livingston DM, Chittenden T: The transcription factor $\mathrm{E} 2 \mathrm{~F}$ interacts with the retinoblastoma product and a p107-cyclin A complex in a cell cycle-regulated manner. Cell 1992, 68:157-166

141. Zhang J, Schweers B, Dyer MA: The first knockout mouse model of retinoblastoma. Cell Cycle 2004, 3:952-959.

142. Berman SD, West JC, Danielian PS, Caron AM, Stone JR, Lees JA: Mutation of p107 exacerbates the consequences of Rb loss in embryonic tissues and causes cardiac and blood vessel defects. Proc Natl Acad Sci USA 2009, 106:14932-14936.

143. Chen D, Livne-bar I, Vanderluit JL, Slack RS, Agochiya M, Bremner R: Cellspecific effects of RB or RB/p107 loss on retinal development implicate an intrinsically death-resistant cell-of-origin in retinoblastoma. Cancer cell 2004, 5:539-551.

doi: $10.1186 / 1747-1028-5-9$

Cite this article as: Wirt and Sage, p107 in the public eye: an Rb understudy and more Cell Division 2010, 5:9

\section{Submit your next manuscript to BioMed Central and take full advantage of:}

- Convenient online submission

- Thorough peer review

- No space constraints or color figure charges

- Immediate publication on acceptance

- Inclusion in PubMed, CAS, Scopus and Google Scholar

- Research which is freely available for redistribution
C Biomed Central 